\title{
São Paulo Advanced School of Comparative Oncology (ESPCA)
}

\author{
Silvia Regina Rogatto ${ }^{1,2}$ \\ From São Paulo Advanced School of Comparative Oncology \\ Águas de São Pedro, Brazil. 30 September - 6 October 2012
}

Comparative Oncology, the theme of this School, is a new area of research and has undergone a special development over the past decades. The focus in this area has increasingly attracted the attention of researchers who are interested in etiopathogenesis, tumor biology, morphogenesis, epidemiology, genomics and cancer therapeutics. Comparative Oncology integrates the study of naturally occurring cancers in animals into studies of human cancer. These studies have enormous potential to discover novel treatments for human beings by treating pet animals, specially dogs and cats with naturally occurring cancer and that share similarities with human cancer genes.

The goal of the São Paulo Advanced School of Comparative Oncology was to promote the consolidation and expansion of basic and applied cancer research in the State of São Paulo. The international exchange of technological and scientific innovation aims to establish a globally competitive hub for talented researchers in this new area.

The ESPCA was attended by 32 speakers from different countries including Brazil, Canada, France, USA, Japan, Netherlands, Germany, Finland, and UK. The School provided an invaluable opportunity for networking and fruitful contacts with cancer researchers working with human and animals.

During the event it was created a Facebook page, on which photos and news concerning the lectures and interviews were daily updated. A journalist was hired to interview the lecturers and participants. Videos were also uploaded to an Youtube account, and the link was shared on the Facebook page. The official website of the School is http://www.comparativeoncologyespca.org/.

\section{Acknowledgements}

Sao Paulo School of Advanced Sciences (SPSAS) was financially supported by São Paulo Research Foundation (FAPESP), Coordination for the Improvement of Higher Education Personnel (CAPES) and the National Council for Scientific and Technological Development (CNPq), Ministry of Higher Education, Brazil. ESPCA was organized through the institutional collaboration between the Graduate Programs of Faculty of Medicine (Pathology, Surgery and Ginecology - http://www.fmb.unesp.br) and Biosciences Institute (Genetics; http://www.ibb.unesp.br) from São Paulo State University, UNESP, Botucatu, São Paulo; Hospital A.C. Camargo, São Paulo (Oncology; http://accamargo.org. br), Faculty of Veterinary Medicine, UNESP, Botucatu (Medical Veterinary http://www.fmvz.unesp.br); Faculty of Veterinary Medicine and Zootechny, University of São Paulo, USP , São Paulo (Experimental and Comparative Pathology - http://www.fmvz.usp.br); and Biosciences Institute, Federal University of Minas Gerais, Belo Horizonte, Brazil. Institutional support was also provided by UNESP (http://www.unesp.br - PROPG, PROPe,) and Brazilian Scientific Societies (ABPV - Brazilian Association of Veterinary Pathology; http://www.abpv.vet.br; ABROVET - Brazilian Association of Veterinary Oncology; http://www.abrovet.org.br, and Brazilian Society of Genetics - SBG, Ribeirão Preto - SP, http://www.sbg.org.br).

\section{Author details}

${ }^{1}$ Faculty of Medicine, São Paulo State University, UNESP, Botucatu, SP, Brazil. ${ }^{2}$ International Center of Research and Training (CIPE), Hospital A.C. Camargo, São Paulo, SP, Brazil.

Published: 4 April 2013

doi:10.1186/1753-6561-7-S2-A1

Cite this article as: Rogatto: São Paulo Advanced School of

Comparative Oncology (ESPCA). BMC Proceedings 2013 7(Suppl 2):A1. 